\title{
COGNITIVE ERGO-ASSESSMENT OF HUMAN FACTOR DURING MANUAL TOLL COLLECTION
}

\author{
JURUM KIPKE, J[asna]; SUMPOR, D[avor] \& MUSABASIC, N[edzad]
}

\begin{abstract}
The paper presents the methodology of ergonomic assessment of the system "human - working environment traffic environment", having collected the input data by surveying the subjective disturbances in 50 male respondents working on manual toll collection. The ergonomic assessment of subjective disturbance factors was realized by means of concrete parameters with numerical values, on the basis of which the dominant and important factors of disturbance per percentage belonging were divided into three standard groups of factors: human factor, working environment and traffic environment. The share of the group of factors 'human factor' was determined and the impact of disturbance factors from the working environment of the toll booth and the traffic environment of the toll station has been assessed.

Key words: manual toll collection, ergonomic assessment, dominant and important factors, three groups, human factor
\end{abstract}

\section{INTRODUCTION}

The authors have studied the hypothesis that the system of simultaneous disturbance factors from the working and/or traffic environment reduces the reliability and safety of employees during manual toll collection on the Zagreb-Rijeka route, and that it is possible by means of the concrete parameters with numerical values to assess the impact of individual disturbance factors in case of employees compared to all the other concurrent disturbance factors. There is a lagging behind in Europe in the cognitive approach in relation to the behaviouristic approach to the study of drivers' behaviour and reactions (Michon, 1985). Identical problem can be found also with the employees in secondary traffic processes. The last 40 years have seen intensified systemic study of the work at night and in shifts (Kroemer \& Grandjean, 1997). Fifty interviewed employees of the Rijeka-Zagreb Highway dd. Company are Croatian citizens of the average age of 39.9, with the average of 13 years of work experience working in manual toll collection, which means also working at night in irregular shifts.

\section{DOMINANT AND IMPORTANT ERGO - ASSESSMENT FACTORS}

The respondents added four factors of subjective disturbance to the fifteen offered in Table 1. They assessed only the factors that present subjective disturbance with grades from 1 upwards. Grade 1 equals the most intensive subjective intensity of disturbance. The dominant factors of disturbances $\mathrm{C}$ and $\mathrm{F}$ from Tables 1 and 2 cause maximal effort by the respondents in the critical working posture, which can be partially studies by the methodology of virtual 3D biomechanical models (Jurum-Kipke et al., 2007).

The influence of individual factors relatively in relation to all the other simultaneous factors has been assessed in Table 2 by numerical value of index of importance $I_{V}$,

\begin{tabular}{|c|c|}
\hline \multicolumn{2}{|r|}{ Factors: 15 offered in survey +4 added* by the respondents } \\
\hline $\mathbf{M}$ & $\begin{array}{l}\text { exhaust gases from motor vehicles (with emphasis on } \\
\text { the smell of heavy vehicle exhaust gases) }\end{array}$ \\
\hline $\mathbf{C}$ & $\begin{array}{l}\text { comfort of the working seat and adjustability of the } \\
\text { height of the seat compared to the worker's tallness. }\end{array}$ \\
\hline $\mathbf{A}$ & $\begin{array}{l}\text { continuous and/or periodical audible traffic noise } \\
\text { during work }\end{array}$ \\
\hline $\mathbf{L}$ & $\begin{array}{l}\text { communication and work with difficult customers and } \\
\text { service users }\end{array}$ \\
\hline $\mathbf{E}$ & $\begin{array}{l}\text { open window (work opening) of the toll booth (summer } \\
\text { heat, winter cold, draught, audible traffic noise) }\end{array}$ \\
\hline $\mathbf{K}$ & $\begin{array}{l}\text { professional diseases (backache, high blood pressure, } \\
\text { haemorrhoids..) }\end{array}$ \\
\hline $\mathbf{F}$ & $\begin{array}{l}\text { uncomfortable working position (turning of the body } \\
\text { during work in the back part of the spine and/or turning } \\
\text { of the spinal neck part) }\end{array}$ \\
\hline $\mathbf{B}$ & sleepiness during night shift \\
\hline $\mathbf{I}$ & $\begin{array}{l}\text { load by vehicle type (high buses and new trucks, smell } \\
\text { from exhaust gases of older trucks, low sport vehicles) }\end{array}$ \\
\hline G & $\begin{array}{l}\text { visibility from the workplace depending on the vehicle } \\
\text { category (height), for the position and form of the work } \\
\text { opening (window) of the toll booth fixed regarding } \\
\text { height }\end{array}$ \\
\hline $\mathbf{H}$ & load by the number of vehicles (congestion) \\
\hline $\mathbf{O}$ & switched on air-conditioning system and open window \\
\hline $\mathbf{N}$ & $\begin{array}{l}\text { glare of light on toll booth window in comparison to } \\
\text { the darker interior }\end{array}$ \\
\hline D & $\begin{array}{l}\text { arrangement of all the necessary equipment for work } \\
\text { within the working toll booth environment (within the } \\
\text { field of visibility and/or at the reach of hand) }\end{array}$ \\
\hline $\mathbf{R}^{*}$ & irregular shift work (disturbed biorhythm) \\
\hline $\mathbf{S}^{*}$ & management ignorance for working conditions \\
\hline $\mathbf{P}^{*}$ & sleepiness during work in the first shift \\
\hline $\mathbf{J}$ & $\begin{array}{l}\text { distraction by the moving of a vehicle right in the field } \\
\text { of peripheral vision (window right) }\end{array}$ \\
\hline $\mathbf{Z}^{*}$ & permanent loss of hearing for high tones \\
\hline
\end{tabular}

Tab. 1. Ergonomics assessment factors

$I_{V}$ defined by expression (1) includes equally the impact of average grade $\bar{o}$ for the intensity of subjective disturbance in $n$ respondents according to formula (2) and the impact of the percentage of occurrence $P(\%)$ of individual subjective disturbance in all the respondents. According to value $I_{V}$ the subjective disturbance factors from Table 1 are in Table 2 divided into groups of dominant (from $M$ to $B$ ), important (from I to $\mathrm{R}^{*}$ ) and negligible (from $\mathrm{S}^{*}$ to $\mathrm{Z}^{*}$ ) ones.

$$
\begin{gathered}
I_{V}=\frac{P}{100} \cdot(10,75-\bar{o}) \\
\bar{o}=\frac{1}{n} \cdot \sum_{i=1}^{n} o
\end{gathered}
$$




\begin{tabular}{|c|c|c|c|c|c|c|}
\hline \multicolumn{2}{|c|}{ Factor } & Group & $P(\%)$ & $\bar{o}$ & $I_{v}$ & $P_{I V}(\%)$ \\
\hline \multirow{8}{*}{ 䒕 } & $\mathrm{M}$ & TE,WE & 88 & 3,23 & 6,620 & 14,13 \\
\hline & $\mathrm{C}$ & $\mathrm{WE}$ & 80 & 3,60 & 5,720 & 12,21 \\
\hline & A & H,WE,TE & 96 & 5,29 & 5,233 & 11,17 \\
\hline & 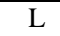 & TE & 72 & 4,22 & 4,700 & 10,03 \\
\hline & $\bar{E}$ & TE,WE & 76 & 5,68 & 3,850 & 8,22 \\
\hline & $\overline{\mathrm{K}}$ & $\mathrm{H}$ & 52 & 4,50 & 3,250 & 6,94 \\
\hline & $\mathrm{F}$ & WE & 56 & 5,00 & 3,220 & 6,87 \\
\hline & B & $\mathrm{H}$ & 64 & 5,84 & 3,140 & 6,70 \\
\hline \multirow{7}{*}{ 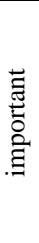 } & I & TE & 56 & 6,82 & 2,200 & 4,70 \\
\hline & G & H,TE,WE & 48 & 6,63 & 1,980 & 4,23 \\
\hline & $\mathrm{H}$ & $\mathrm{TE}$ & 40 & 6,15 & 1,840 & 3,93 \\
\hline & $\mathrm{O}$ & $\mathrm{WE}$ & 42 & 6,57 & 1,755 & 3,75 \\
\hline & $\mathrm{N}$ & TE,WE & 42 & 7,05 & 1,555 & 3,32 \\
\hline & $\mathrm{D}$ & WE & 32 & 6,63 & 1,320 & 2,82 \\
\hline & $\mathrm{R}^{*}$ & $\mathrm{H}$ & 8 & 5,00 & 0,460 & 0,98 \\
\hline \multicolumn{5}{|c|}{ dominant factors $(\mathrm{M}-\mathrm{B})-$ Table 1} & 35,73 & 76,28 \\
\hline \multicolumn{5}{|c|}{ important factors $(\mathrm{I}-\mathrm{R} *)-$ Table 1} & 11,11 & 23,72 \\
\hline \multicolumn{5}{|c|}{ negligible factors $\left(\mathrm{S}^{*}-\mathrm{Z}^{*}\right)-$ Table 1} & 0,485 & 1 \\
\hline \multicolumn{5}{|c|}{ total without negligible factors } & 46,84 & 100,0 \\
\hline \multirow{3}{*}{\multicolumn{3}{|c|}{$\begin{array}{l}\text { partial influence of } \\
\text { individual group of } \\
\text { factors }\end{array}$}} & \multicolumn{3}{|c|}{$\mathrm{WE}=$ working environment } & 25,65 \\
\hline & & & \multicolumn{3}{|c|}{$\mathrm{TE}=$ traffic environment } & 18,66 \\
\hline & & & \multicolumn{3}{|c|}{$\mathrm{H}=$ human } & 14,62 \\
\hline \multirow{3}{*}{\multicolumn{3}{|c|}{$\begin{array}{l}\text { overlapping of two } \\
\text { groups of factors }\end{array}$}} & \multicolumn{3}{|c|}{$\mathrm{H}+\mathrm{TE}$} & 0,00 \\
\hline & & & \multicolumn{3}{|c|}{$\mathrm{H}+\mathrm{WE}$} & 0,00 \\
\hline & & & & $\mathrm{NE}+\mathrm{TE}$ & & 25,67 \\
\hline \multicolumn{3}{|c|}{$\begin{array}{l}\text { overlapping of three } \\
\text { groups }\end{array}$} & \multicolumn{3}{|c|}{$\mathrm{H}+\mathrm{WE}+\mathrm{TE}$} & 15,40 \\
\hline \multirow{3}{*}{\multicolumn{3}{|c|}{$\begin{array}{l}\text { collective influence of } \\
\text { individual group of } \\
\text { factors }\end{array}$}} & \multicolumn{3}{|c|}{ WE with all overlaps } & 66,72 \\
\hline & & & \multicolumn{3}{|c|}{ TE with all overlaps } & 59,73 \\
\hline & & & \multicolumn{3}{|c|}{$\mathrm{H}$ with all overlaps } & 30,02 \\
\hline
\end{tabular}

Tab. 2. Belonging of 15 dominant and important factors of disturbance to 3 standard groups: $\mathrm{H}, \mathrm{WE}$ and TE

The dominant and important factors of subjective disturbances in Table 2 have been assigned the belonging to three standard groups: human factor $(\mathrm{H})$, working environment (WE) and traffic environment (TE). The parameter of percentage belonging of individual factor $P_{I V}(\%)$ in Table 2 has been defined by expression (3).

$$
P_{I v}=\frac{I v_{i}}{\sum_{i=1}^{15} I v_{i}} \cdot 100
$$

\section{RESEARCH RESULTS}

The methodology of determining the percentage belonging of the disturbance factors in the group of factors 'human factor' was implemented for the first time by the authors while studying the subjective disturbance factors in case of 50 engine drivers (Jurum-Kipke et al., 2011). In the task - capability interface model (Fuller, 2005) the group of factors 'human factor', dynamically and concurrently changes also the capability of employees and the task demand. If the task demand becomes larger than the employee's capability, there will be no loss of control over the vehicle, as is the case with drivers, but the slowed down work of the employees under workload of manual toll collection will slow down the flow of road traffic on the motorway.

Figure 1 presents the results expressed by $P_{I v}$. The boxes below the symbol denoting the title of the group of factors in Figure 1 contain the collective percentage share of the factors in three standard groups, with all the overlappings. The lowest partial and collective percentage belonging of $30.02 \%$ for the group of factors 'human factor' $(\mathrm{H})$ in relation to $66.72 \%$ for the working environment (WE) and $59.73 \%$ for the traffic environment (TE) prove the non-ergonomic design of the toll booths and the toll station.

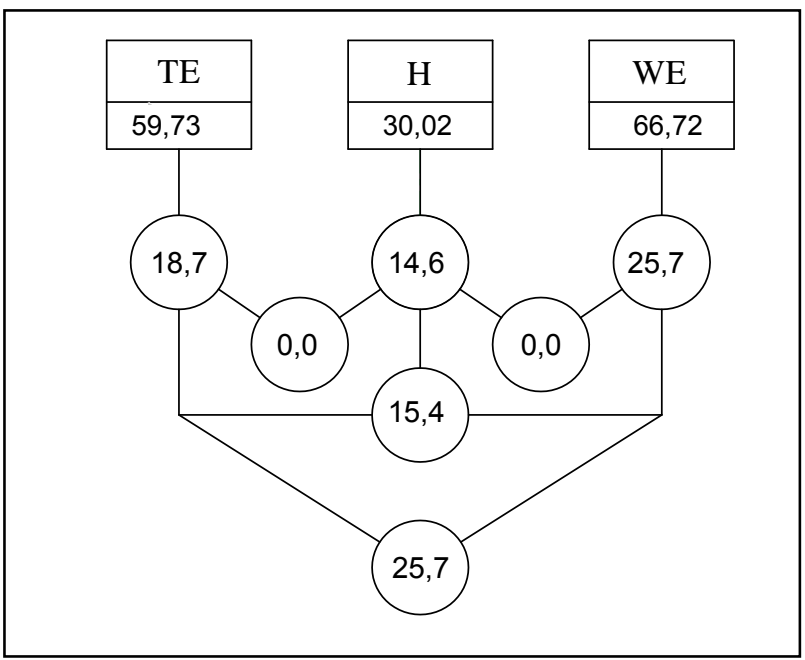

Fig. 1. Human factor (H) in manual toll collection expressed by $P_{I v}(\%)$

\section{CONCLUSION}

In the paper the hypothesis has been proven that it is possible to determine the share of the group of factors 'human factor' by means of concrete parameters with numerical values for assessing the impact of dominant and important factors of subjective disturbance. Subjective disturbances of the employees working in manual toll collection are related to the occurrence or change of the concrete factors in the working and/or traffic environment, which is the principle of modern conceptual ergonomics due to equal recognition of the cognitive and behaviouristic principle of research. The research results show that the impact of the disturbance factors from the woking environment of the toll booth and the traffic environment of the toll station is dominant in relation to the group of factors 'human factor'.

\section{REFERENCES}

Fuller, R. (2005). Towards a general theory of driver behaviour, Accident Analysis and prevention 37, Issue 3, Elsevier, May 2005, pp. 461-472, ISSN: 0001-4575

Jurum - Kipke, J.; Sumpor, D. \& Rožić, T. (2007). Scientific 3D Biomechanical Analysis of Work in Airbus A320 Cargo Hold, Annals of DAAAM for 2007 \& Proceedings of $18^{\text {th }}$ International DAAAM Symposium "Intelligent Manufacturing \& Automation: Focus on Creativity, Responsibility, and Ethics of Engineers ", $24^{\text {th }}-27^{\text {th }}$ October 2007, Zadar, Croatia, ISSN: 1726-9679, ISBN: 3901509-58-5, Katalinic, B. (Ed.), pp. 365-366, Published by DAAAM International, Vienna, Austria

Jurum-Kipke, J.; Sumpor, D. \& Musabašić, N. (2011). Cognitive Ergo-Assessment of Human Factor in Railway Traffic in the Republic of Croatia, Proceedings of the 19th International Symposium on Electronics in Traffic ISEP 2011, ITS - Connecting Transport, March 28, Ljubljana, Slovenia, ISBN: 978-961-6187-49-7, Anžek, M. at al. (Eds.), W5, 6 p., Electrotechnical Association of Slovenia, Ljubljana

Kroemer, K.H.E. \& Grandjean, E. (1997). Fitting the Task to the Human, A Textbook of Occupational Ergonomics, Fifth Edition, Published by Taylor \& Francis Ltd., ISBN: 0748406654, London

Michon, J. A. (1985). A critical review of driver behavior models: What do we now, what should we do? In: Human Behavior and Traffic Safety, L. Evans and R. C. Schwing (Eds.), pp. 485-520, Plenum Press, ISBN: 0306422255, New York 